\title{
Does capital intensity, inventory intensity, firm size, firm risk, and political connections affect tax aggressiveness?
}

\author{
Sugeng $^{1 *}$, Eko Prasetyo ${ }^{2}$, Badrus Zaman ${ }^{3}$ \\ ${ }^{1}$ Department of Accounting, Faculty of Economics, Universitas Nusantara PGRI Kediri, \\ Kediri, Indonesia \\ ${ }^{2}$ Department of Accounting, Faculty of Economics and Business, Universitas Kahuripan \\ Kediri, Kediri, Indonesia \\ ${ }^{3}$ Department of Accounting, Faculty of Economics, Universitas Nusantara PGRI Kediri, \\ Kediri, Indonesia \\ *Corresponding Author(s) Email: sugengprismakat@gmail.com
}

\begin{abstract}
Tax aggressiveness is one of a critical issue in the world of taxation. Many companies do tax planning to minimize their tax abilities. This study aims to examine how capital intensity, inventory intensity, firm size, firm risk, and political connections, relate to the tax aggressiveness of manufacturing listed companies in Indonesia, an emerging economy of Southeast Asia. This study combined the tax aggressiveness factor from different perspectives into one model. This study used purposive sampling with manufacturing companies listed in Indonesia Stock Exchange during 2015-2017 and experienced a consecutive profit as the main criteria. Panel data regression used as a data analysis technique. The result shows that there is a significant effect between capital intensity, political connection, and tax aggressiveness. The relationship between inventory intensity, firm size, firm risk, and tax aggressiveness failed to prove in this study. This result is consistent across several measures of tax aggressiveness.
\end{abstract}

Keywords: Capital Intensity; Inventory Intensity; Firm Size; Firm Risk; Political Connection; Tax Aggressiveness

JEL Code:

$\mathrm{H} 26$

DOI:

10.31106/jema.v17i1.3609

Article History:

Received 2019-07-24

Reviewed 2019-11-30

Revised 2019-12-25

Accepted 2020-01-28

Licensed:

CC-BY 


\section{Introduction}

Although, tax is one of the important sources for the country to finance their expenditures (both for expenditure routine and development expenditure). The fact that the ratio of Indonesia tax revenue which is below the standards of ASEAN countries indicates that there is some gap that needs to be explored (Subadriyah \& Aliyah, 2018). Carolina et al. (2014) argued that for companies, tax is a burden that can reduce the company's net income. Companies tend to be aggressive in taxation and looking for ways to reduce their burden through various tax planning treatment both legally (tax avoidance) or even illegal.

Several factors can influence the tax aggressiveness of companies. Dunbar et al. (2010) argue that capital intensity (company investment in fixed asset) correlates with overall tax planning opportunities. Richardson et al. (2016) added that capital intensity is positively associated with tax aggressiveness due to the accelerated depreciation charges based on a fixed asset. Thus, inventory-intensive firms should be negatively associated with tax aggressiveness which means the larger the inventory level of companies, the smaller the tax avoidance intention (Stickney \& McGee, 1982).

On the other hand, Lanis \& Richardson, (2012), Sari \& Tjen (2016), and Devi et al. (2018) concluded that firm size is positively and significantly affect tax aggressiveness which means that the larger the size of the firm the more aggressive the tax policy. Guenther et al. (2017) add firm risk as a determinant of corporate tax aggressiveness and tax avoidance. He concluded that there is a positive correlation between firm risk, tax aggressiveness, and tax avoidance. Kim \& Zhang (2016), Abdul Wahab et al. (2017), and Ying et al. (2017) included political connections as another predictor of tax aggressiveness. They concluded that politically connected firms would be more aggressive in their tax policy rather than nonpolitical connected firms.

Briefly, there are five factors at least that can enhance the tax aggressiveness intention of the company namely capital intensity, inventory intensity, firm size, risk, and political connections. Interestingly, there are 3 of the five factors mentioned above still debatable since there is another research that concluded differently. For inventory intensity in an example, research from Savitri \& Rahmawati (2017) found that the inventory intensity per se does not influence tax aggressiveness which is contradictory with Stickney \& McGee (1982) and Nurfauzi \& Firmansyah (2018) conclusion. Recent research from Rusydi (2013) and Ann \& Manurung (2019), also show the different conclusion. While Rusydi (2013) concluded that firm size has no influence on tax aggressiveness, Ann \& Manurung (2019) stated that firm 
size has a negative and significant effect on tax aggressiveness. Therefore, the fact that there is a different conclusion of the effect of inventory intensity, firm size, firm risk on tax aggressiveness needs to be explored. This research aims to analyze capital intensity, inventory intensity, firm size, firm risk, and political connections on tax aggressiveness of listed manufacturing companies in the Indonesia Stock Exchange (2015-2017). This study chose the manufacturing sector since it has the greatest contribution compared with other sectors.

\section{Literature Review}

\section{Capital Intensity}

Lubatkin \& Chatterjee (1994) stated that capital intensity is often considered as representative of firm operating leverage. Nugraha \& Mulyani (2019) defined capital intensity as the amount of fixed asset investment activities carried out by companies. (Stickney \& McGee, 1982) added that capital intensity can be measured as gross plant assets/total assets, net plan asset/total asset, depreciation and amortization expense/number of employees, gross plan assets/number of employees. The formula used in this research is;

Capital Intensity $=\frac{\text { Total Fixed Assets }}{\text { Total Assets }}$

Dunbar et al. (2010) and Richardson et al. (2016) concluded that capital intensity has a positive relationship with tax aggressiveness.

$\mathrm{H}_{1}$ : There is a significant relationship between capital intensity and tax aggressiveness.

\section{Inventory Intensity}

Inventory intensity considered one of the most crucial firm-specific characteristics that can influences tax aggressiveness. Devi et al. (2018) defined inventory intensity as the level of investment that occupied by the company on its inventory. Stickney \& McGee (1982) and Nurfauzi \& Firmansyah (2018) concluded that there is a negative correlation between inventory intensity and tax aggressiveness. The larger the inventory level of companies, the smaller the tax avoidance intention. Inventory intensity in this study is measured as inventory divided by total assets (Richardson \& Lanis, 2007).

$\mathrm{H}_{2}$ : There is a significant relationship between inventory intensity and tax aggressiveness.

Inventory Intensity $=\frac{\text { Total Inventory }}{\text { Total Assets }}$ 


\section{Firm Size}

The size of a company can affect taxes in several ways which are tax aggressiveness by nature and tax reduction by using political advantage. (Kim \& Im, 2017) added that based on the theory of cost it can be concluded that the larger $t$ e size and profit of companies, the higher possibilities of companies doing tax aggressiveness by nature. While based on political theory, the larger size of companies means the higher political advantage so that it can carry out tax planning to reduce taxes that must be paid to the state using existing gaps. Dunbar et al. (2010) and Allen et al. (2016) measured firm size as the natural logarithm of the firm total asset.

Firm Size $=$ Ln(Total Assets $)$

Lanis \& Richardson (2012), Sari \& Tjen (2016), Devi et al. (2018) stated that firm size is positively and significantly affect tax aggressiveness which means the larger firms are, the more they will undertake an action to minimize their tax (Halioui et al. 2016).

$\mathrm{H}_{3}$ : There is a significant relationship between firm size and tax aggressiveness.

\section{Firm Risk}

Paligorova \& Santos (2017) defined firm risk as to the volatility of earnings which can be measured by the standard deviation formula. The greater the deviation of earnings in the company, the greater the risk of the company. The formula used to measure firm risk is;

Risk $=\sqrt{\sum_{T-1}^{T}\left(E-1 / T \sum_{T-1}^{T} E\right)^{2} /(T-1)}$

Research from Guenther et al. (2017) and Chang et al. (2015) concluded that the firm risks affect tax aggressiveness behavior. Therefore, the proposed hypothesis of this research is, $\mathrm{H}_{4}$ : There is a significant relationship between firm risk and tax aggressiveness

\section{Political Connection}

The political connection is a dilemma that plagues its capital market. Political connection classified by Bliss \& Gul (2012) into three definitions which is the percentage of direct government equity ownership; the percentage of equity owned by "institutional" investors, firms that have informal ties with powerful politicians. Ying (2011), Wu et al. (2012), Kim \& Zhang (2016), Abdul Wahab et al. (2017), Ying et al. (2017) added that in the term of tax aggressiveness, politically connected firms would be more aggressive in its tax policy rather than non-political connected firms. In this study, the political connections used dummy 
variables as a proxy. It will be given a value of 1 if there is ownership by the government in the company vice versa.

$\mathrm{H}_{5}$ : There is a significant relationship between political connection and tax aggressiveness.

\section{Tax Aggressiveness}

Abdul Wahab et al. (2017) defined tax aggressiveness as the downward management of taxable income through tax-planning activities. The primary goal of this tax activities is to reduce the tax bill of the companies. The terminology of tax avoidance and tax aggressiveness have been used interchangeably. Lietz (2013) prefers to classified tax aggressiveness as part of tax avoidance despite their legal, illegal, or gray-scaled behavior. Lanis \& Richardson (2012) argued that proxies that are most commonly used to measure the aggressiveness of the tax are ETR. The formula used is;

$E T R=\frac{\text { Total } \operatorname{Tax}}{\text { Earnings Before } \operatorname{Tax}}$

\section{Methods}

Figure 1. Research Framework

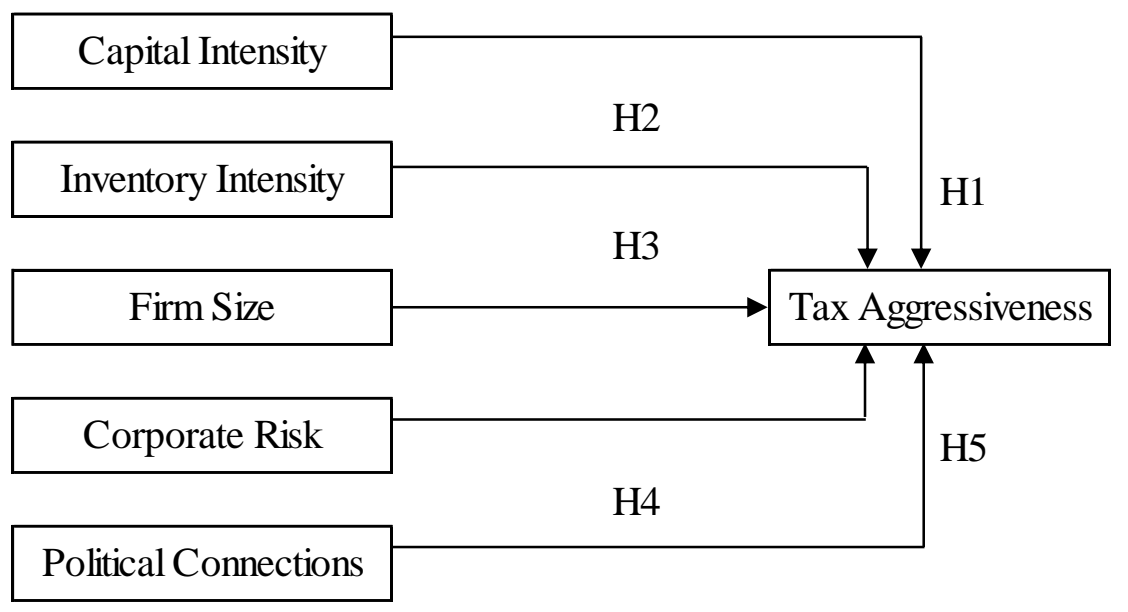

The design used in this study was quantitative with panel data regression used as a data analysis technique. The research was designed to focus on manufacturing companies listed in Indonesia Stock Exchange (IDX) for 2015-2017 periods, publish their financial report publicly, experienced a consecutive profit, and share their dividend. There are 37 manufacturing companies for the 2015-2017 periods observed in this study. This study has a conceptual framework as seen in Figure 1. The model should pass all classical assumption testing like normality, multicollinearity, autocorrelation, and heteroscedasticity. Data is normally distributed if the significance value of Kolmogorov-Smirnov (KS) is larger than 0.050. Meanwhile, to pass the multicollinearity test, the value of Tolerance and VIF should 
be higher than 0.400 and lower than 10. Detection of autocorrelation can be done with the Durbin-Watson test which means that if the value of Durbin-Watson (DW) was lower than 1 or greater than 3 indicate autocorrelation. For the heteroscedasticity test, there is an indication of homoscedasticity if the probability value of the Glejser test results is lower than 0.050. Based on Table 1, it can be concluded that the model passes all classical assumption test.

Table 1. Normality, Multicollinearity, Autocorrelation, and Heteroscedasticity Test

\begin{tabular}{llcc}
\hline Model Test & & Statistical Criteria & Statistical Value \\
\hline Autocorrelation & Durbin Watson & $1.000<\mathrm{DW}<3.000$ & 1.795 \\
Multicollinearity & Tolerance & $>0.400$ & $0.903 ; 0.892 ; 0.289 ; 0.281 ; 0.882$ \\
& VIF & $<10.000$ & $1.107 ; 1.121 ; 3.458 ; 3.559 ; 1.134$ \\
Heteroscedasticity & Prob. Value & $>0.050$ & $0.055 ; 0.730 ; 0.066 ; 0.436 ; 0.182$ \\
Normality & Sig. Value of 1-KS & $>0.050$ & 0.150 \\
\hline
\end{tabular}

\section{Result and Discussion}

Table 2. Hypothesis Testing

\begin{tabular}{lccc}
\hline Model & t Value & Sig. & Decision \\
\hline Capital Intensity -> Tax Aggressiveness & 7.921 & 0.000 & $\mathrm{H}_{1}$ Accepted \\
Inventory Intensity -> Tax Aggressiveness & 1.695 & 0.093 & $\mathrm{H}_{2}$ Rejected \\
Firm Size -> Tax Aggressiveness & 0.450 & 0.654 & $\mathrm{H}_{3}$ Rejected \\
Firm Risk -> Tax Aggressiveness & -1.719 & 0.089 & $\mathrm{H}_{4}$ Rejected \\
Political Connection -> Tax Aggressiveness & 1.316 & 0.019 & $\mathrm{H}_{5}$ Accepted \\
\hline
\end{tabular}

This study supports previous studies by Dunbar et al. (2010) and Richardson et al. (2016) that stated there was a significant relationship between capital intensity on tax aggressiveness. The significant values of that relationship (0.000) were lower than 0.050 which means that $\mathrm{H}_{1}$ is accepted. (Sonia \& Suparmun, 2019) added that the company which has high capital intensity tend to do tax avoidance practice legally since the fixed assets can reduce their tax bill by the depreciation. Thus, the depreciation can reduce the company's profit directly while doing tax calculation. This study also concluded that political connection has a significant relationship on tax aggressiveness. The significant values of that relationship (0.019) were lower than 0.050 which means that $\mathrm{H}_{5}$ is accepted. Adhikari et al. (2006) added that company with politically connected tend to do tax planning aggressively than non- 
politically connected company since they have a better information regarding tax regulations and enforcement, lower political cost, lower transparency (Kim \& Zhang, 2016), incentives, enforce tax legislations, and freedom to overlap policies to gain more tax benefit.

Unfortunately, this study failed to prove the proposed hypothesis which stated that there is a significant partial relationship between inventory intensity, firm size, firm risk, and tax aggressiveness. The significant values of that relationship $(0.093 ; 0.654 ; 0.089)$ were higher than 0.050 which means that $\mathrm{H}_{2}, \mathrm{H}_{3}, \mathrm{H}_{4}$ are rejected. Nurhayati et al. (2019) argued that inventory as part of the investment is not the best-suited strategy to minimize tax burden since companies which have a higher level of inventory perceived as worse market position due to their low level of inventory. Richardson \& Lanis (2007) added that companies that can be classified into big size company categories have limited action to do tax planning due to the high surveillance level of government, financial analyst, and media. Their big size visibility causes them to become easy targets of the tax regulator. Therefore, it is too risky for them to do tax planning especially when they experienced a consecutive profit. Firmansyah \& Muliana (2018) added that tax avoidance could enhance the firm risk for several reasons like the uncertainty of future tax payments and serve as bad leading indicators of firm risk.

\section{Conclusion and Suggestion}

Our study has provided empirical evidence on tax aggressiveness behavior in Indonesia. We have managed to expose the effect of capital intensity, inventory intensity, firm size, firm risk, and political connections on tax aggressiveness. Using a sample of manufacturing listed companies in Indonesia covering the period from 2015 to 2017, we find that there is a significant effect between capital intensity, political connection, and tax aggressiveness. It means that the higher the capital intensity and politically connected, the higher the tendencies of a company to do tax planning aggressively. However, we have no evidence to prove our proposed hypothesis regarding the effect of inventory intensity, firm size, firm risk on tax aggressiveness. The previous study claimed that inventory as part of the investment is not the best-suited strategy to minimize the tax burden. As the bigger the size of the company, the higher the risk of a company to do tax planning due to the high surveillance level of government. Further research should focus on the different industries and explore the external and internal factors of tax aggressiveness.

\section{References}

Abdul Wahab, E. A., Ariff, A. M., Madah Marzuki, M., \& Mohd Sanusi, Z. (2017). Political 
connections, corporate governance, and tax aggressiveness in Malaysia. Asian Review of Accounting, 25(3), 424-451. https://doi.org/10.1108/ARA-05-2016-0053

Adhikari, A., Derashid, C., \& Zhang, H. (2006). Public policy, political connections, and effective tax rates: Longitudinal evidence from Malaysia. Journal of Accounting and Public Policy, 25(5), 574-595. https://doi.org/10.1016/j.jaccpubpol.2006.07.001

Allen, A., Francis, B. B., Wu, Q., \& Zhao, Y. (2016). Analyst coverage and corporate tax aggressiveness. Journal of Banking \& Finance, 73, 84-98. https://doi.org/10.1016/j.jbankfin.2016.09.004

Ann, S., \& Manurung, A. H. (2019). The Influence of Liquidity,Profitability,Intensity Inventory,Related Party Debt,And Company Size To Aggressive Tax Rate. Archives of Business Research, 7(3), 105-115. https://doi.org/10.14738/abr.73.6319

Bliss, M. A., \& Gul, F. A. (2012). Political connection and cost of debt: Some Malaysian evidence. Journal of Banking \& Finance, 36(5), 1520-1527. https://doi.org/10.1016/j.jbankfin.2011.12.011

Carolina, V., Natalia, M., \& Debbianita, D. (2014). Karakteristik eksekutif terhadap tax avoidance dengan leverage sebagai variabel intervening. Jurnal Keuangan Dan Perbankan, 18(3), 409-419.

Chang, C.-S., Yu, S.-W., \& Hung, C.-H. (2015). Firm risk and performance: The role of corporate governance. Review of Managerial Science, 9(1), 141-173. https://doi.org/10.1007/s11846-014-0132-x

Devi, M. N., Salim, A. S. A., \& Pheng, L. K. (2018). The impact of firm characteristics on corporate tax aggressiveness: A study on malaysian public listed companies. Advanced Science Letters, 24(4), 2208-2212. https://doi.org/10.1166/asl.2018.10918

Dunbar, A., Higgins, D. M., Phillips, J. D., \& Plesko, G. A. (2010). What do measures of tax aggressiveness measure? In National Tax Association Proceedings (pp. 18-26).

Firmansyah, A., \& Muliana, R. (2018). The effect of tax avoidance and tax risk on corporate risk. Jurnal Keuangan Dan Perbankan, 22(4), 643-656. https://doi.org/10.26905/jkdp.v22i4.2237

Guenther, D. A., Matsunaga, S. R., \& Williams, B. M. (2017). Is tax avoidance related to firm risk? The Accounting Review, 92(1), 115-136. https://doi.org/10.2308/accr-51408 
Halioui, K., Neifar, S., \& Ben Abdelaziz, F. (2016). Corporate governance, CEO compensation and tax aggressiveness. Review of Accounting and Finance, 15(4), 445462. https://doi.org/10.1108/RAF-01-2015-0018

Kim, C. F., \& Zhang, L. (2016). Corporate political connections and tax aggressiveness. Contemporary Accounting Research, 33(1), 78-114. https://doi.org/10.1111/19113846.12150

Kim, J. H., \& Im, C. C. (2017). The study on the effect and determinants of small - and medium-sized entities conducting tax avoidance. Journal of Applied Business Research (JABR), 33(2), 375-390. https://doi.org/10.19030/jabr.v33i2.9911

Lanis, R., \& Richardson, G. (2012). Corporate social responsibility and tax aggressiveness: An empirical analysis. Journal of Accounting and Public Policy, 31(1), 86-108. https://doi.org/10.1016/j.jaccpubpol.2011.10.006

Lietz, G. M. (2013). Tax avoidance vs. Tax aggressiveness: a unifying conceptual framework. SSRN Electronic Journal. https://doi.org/10.2139/ssrn.2363828

Lubatkin, M., \& Chatterjee, S. (1994). Extending modern portfolio theory into the domain of corporate diversification: Does it apply? Academy of Management Journal, 37(1), 109136. https://doi.org/10.5465/256772

Nugraha, M. I., \& Mulyani, S. D. (2019). Peran leverage sebagai pemediasi pengaruh karakter eksekutif, kompensasi eksekutif, capital intensity, dan sales growth terhadap tax avoidance. Jurnal Akuntansi Trisakti, 6(2), 301-324. https://doi.org/10.25105/jat.v6i2.5575

Nurfauzi, R., \& Firmansyah, A. (2018). Managerial ability, management compensation, bankruptcy risk, tax aggressiveness. Media Riset Akuntansi, Auditing \& Informasi, 18(1), 75. https://doi.org/10.25105/mraai.v18i1.2775

Nurhayati, Didik, S., \& Luk, L. F. (2019). The effect of financial policy on tax aggressiveness for manufacturing companies listed at indonesia stock exchange. Modern Economics, 13(1), 180-186. https://doi.org/10.31521/modecon.V13(2019)-28

Paligorova, T., \& Santos, J. A. C. (2017). Monetary policy and bank risk-taking: Evidence from the corporate loan market. Journal of Financial Intermediation, 30, 35-49. https://doi.org/10.1016/j.jfi.2016.11.003

Richardson, G., \& Lanis, R. (2007). Determinants of the variability in corporate effective tax 
rates and tax reform: Evidence from Australia. Journal of Accounting and Public Policy, 26(6), 689-704. https://doi.org/10.1016/j.jaccpubpol.2007.10.003

Richardson, G., Taylor, G., \& Lanis, R. (2016). Women on the board of directors and corporate tax aggressiveness in Australia An empirical analysis. Accounting Research Journal, 29(3), 313-331.. https://doi.org/10.1108/ARJ-09-2014-0079

Rusydi, M. K. (2013). Pengaruh ukuran perusahaan terhadap aggressive tax avoidance di indonesia. Jurnal Akuntansi Multiparadigma, 4(2), 323-329. https://doi.org/10.18202/jamal.2013.08.7200

Sari, D., \& Tjen, C. (2016). Corporate social responsibility disclosure, environmental performance, and tax aggressiveness. International Research Journal of Business Studies, 9(2), 93-104. https://doi.org/10.21632/irjbs.9.2.93-104

Savitri, D. A. M., \& Rahmawati, I. N. (2017). Pengaruh leverage, intensitas persediaan, intensitas aset tetap, dan profitabilitas terhadap agresivitas pajak. Jurnal Ilmu Manajemen Dan Akuntansi Terapan, 8(2), 19-32. Retrieved from http://203.190.115.143/jurnal.stietotalwin.ac.id/index.php/jimat/article/view/142

Sonia, S., \& Suparmun, H. (2019). Factors influencing tax avoidance. In 5th Annual International Conference on Accounting Research (AICAR 2018).

Stickney, C. P., \& McGee, V. E. (1982). Effective corporate tax rates the effect of size, capital intensity, leverage, and other factors. Journal of Accounting and Public Policy, 1(2), 125-152. https://doi.org/10.1016/S0278-4254(82)80004-5

Subadriyah, S., \& Aliyah, S. (2018). The differences of taxpayer compliance before and after tax amnesty stimulus. JEMA: Jurnal Ilmiah Bidang Akuntansi Dan Manajemen, 15(2), 98-107. https://doi.org/10.31106/jema.v15i2.1024

Wu, W., Wu, C., Zhou, C., \& Wu, J. (2012). Political connections, tax benefits and firm performance: Evidence from China. Journal of Accounting and Public Policy, 31(3), 277-300. https://doi.org/10.1016/j.jaccpubpol.2011.10.005

Ying, T., Wright, B., \& Huang, W. (2017). Ownership structure and tax aggressiveness of Chinese listed companies. International Journal of Accounting \& Information Management, 25(3), 313-332. https://doi.org/10.1108/IJAIM-07-2016-0070

Ying, Z. (2011). Ownership Structure, Board Characteristics and Tax Aggressiveness. Search. https://doi.org/10.1523/JNEUROSCI.3318-15.2016 